\title{
A Geospatial Assessment of Deforestation of Sokponba and Ehor Forest Reserves in Edo State
}

\author{
A.C. Iyekekpolor and T.F. Balogun* \\ Department of Geography and Regional Planning, University of Benin, \\ Benin City, Nigeria
}

Date Received: 09-02-2020

Date Accepted: 25-06-2020

\begin{abstract}
The study assesses the state of Sokponba and Ehor forest reserves in Edo state, with Landsat images of 1987, 2002 and 2018 using ENVI and ArcGIS software. Questionnaire was also administered to elicit information from respondents. The study reveals that within the period of 31 years under study Sokponba forest reserve has reduced from 28,913.63 ha in 1987 to 1,578.15 ha in 2018 while plantation and farmland increased from 15,357.96 ha in 1987 to 43,494.21 in 2018. Ehor reserve also reduced from $11,128.86$ ha in 1987 to $3,242.28$ in 2018. In the same vein, plantation and farmland increased from $1,424.97$ ha in 1,987 to $9,323.28$ ha in 2018. The deliberate government policies of allocating compartment to timber contractors for logging, conversion of reserves to oil palm plantation and farmland were identified as the major drivers responsible for the depletion of the forest reserves. Considering the consequential effects arising from deforestation such as carbon sequence, greenhouse effect (global warming) and flooding the study recommends reforestation and taungya farming system for sustainable environment.
\end{abstract}

Keywords: reserves, geospatial, deforestation, global warming, reforestation

\section{Introduction}

Forest reserves are areas of forest designated by the government for the protection of trees growing or planted in order to preserve a particular type of habitat and its flora and fauna which are often considered rare or endangered (Usman and Adefalu, 2010; Farlex, 2014). Forest reserves are thus areas of forests which are reserved and managed for conservation and to provide special opportunities for study or research. According to Oyebo (2006), Nigeria has a total of 1,160 constituted forest reserves, covering a total land area of 10, 752,702 ha, representing about $10 \%$ of the total land area. Forests, according to Food and Agriculture Organization (2010), provide support for one billion people that live in extreme poverty around the world and provide remunerative employment to more than one hundred million. They contain more than $80 \%$ of terrestrial biodiversity and provide essential environmental services such as soil conservation, water shed management, protection against floods and landslides, sources of industrial woods (Aweto, 1990; Ojonigu et al., 2009) effective sink for carbon dioxide and release of oxygen (Oduntan et al., 2012). Despite these benefits, forests are currently under severe human interference which is distorting its natural state and impacting negatively on the biodiversity composition and the environment. The continued indiscriminate cutting down of trees without replacement for constructions, fuel wood, agricultural purpose, grasing and hunting, has led to the degradation of the forest ecosystem, extinction of valuable trees, wildlife and loss of biodiversity. Cullen et al. (2011) are of the view that at least $18 \%$ of global greenhouse (GHG) emissions, a major cause of climate change worldwide is attributable to deforestation.

*Correspondence: francis.balogun@uniben.edu

Tel: +2348057378533

(C)University of Sri Jayewardenepura 
FAO (2010) further observed that in Africa, Nigeria is among the five countries with the largest annual net loss of forest for 2000-2010, with 3.7\%. The situation has not changed. Between the periods of 2005 to 2010, about 410,100 ha of forest was lost per year. (Batta et al., 2013) observed that Nigeria has one of the largest rates of deforestation in the world; the country has lost $55.7 \%$ of its primary forest. Olakunle et al. (2011) opined that the main drivers of deforestation in the country are agriculture, logging and mining. Considering the alarming rate of forest depletion in Nigeria and the consequential effect of global warming and flooding, it becomes paramount to monitor our forest reserve in Nigeria. This paper therefore assesses the state of Sokponba and Ehor Forest Reserves using satellite data and questionnaire survey to determine the driver responsible for forest depletion in Nigeria.

\section{Methodology}

\subsection{The study area}

Two forest reserves, Sakponba forest reserve in Orhionmwon LGA and Ehor forest reserve in Uhunmwonde LGA were selected out of 23 forest reserves in Edo State for detailed study (Figure 1). Sokponba forest reserve was constituted in 1912 while Ehor forest reserve was constituted in 1950. Sokponba reserve covers an area of 49,210 ha while Ehor covers a total area of 29,566 ha. The total area coverage of the forest reserves under study is put at 78,776 ha. The Sokponba forest reserve is located between latitude $6^{\circ} 12^{\prime} 10.49^{\prime /} \mathrm{N}$ and $5^{\circ} 58^{\prime} 15.29^{\prime /} \mathrm{N}$ and between longitude $5^{\circ} 49^{\prime} 46.42^{\prime \prime} \mathrm{E}$ and $5^{\circ} 52^{\prime} 11.63^{\prime \prime}$ E. while the Ehor BC16/1 forest reserve spans between latitude $6^{\circ} 23^{\prime} 33.89^{\prime \prime} \mathrm{N}$ and $6^{\circ} 26^{\prime} 10.38^{\prime \prime} \mathrm{N}$ and longitude $5^{\circ} 57^{\prime} 55.42^{\prime \prime} \mathrm{E}$ and $6^{\circ} 6^{\prime} 6.59^{\prime /}$ E. Sokponba forest reserve has 176 compartments, and Ehor BC16/1, 114 compartments. There are several villages in and around the forest reserves areas.

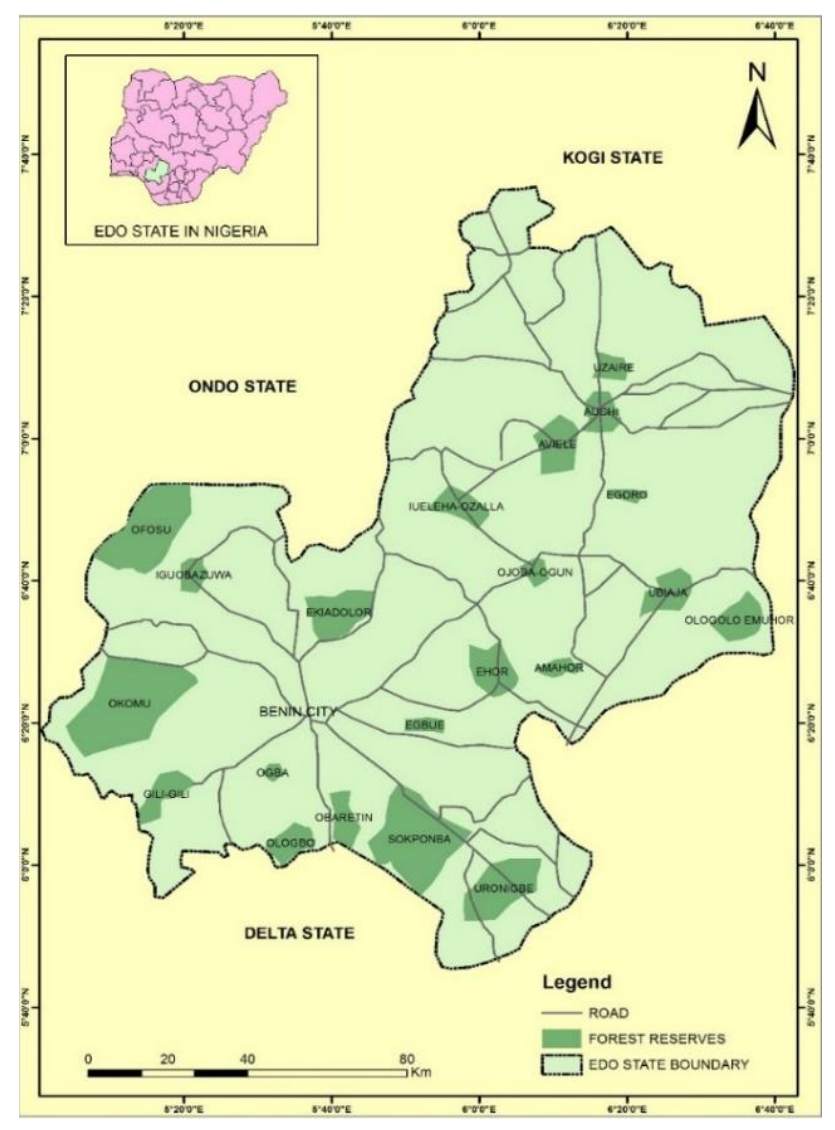

Figure 1. Forest reserves in Edo state. 
Sokponba and Ehor forest reserves are tropical rainforest, rich in economic valuable trees such as Opepe, Afara, Mahogany, Albizia, Alstonia, Okwen and several others which are made up of three layers with a close canopy. These forests serve as source of income generation to the government, communities and individuals, through lumbering, logging and farming activities taking place in the forest. The socio-economic activities of the communities in the study areas is mainly subsistence farming. Crops such as cassava, yams, plantain are cultivated.

\subsection{Data collection}

All the works reviewed i.e., Foody (2003), Fearnside et al. (2004), Kumar et al. (2010), Ati et al. (2010), Naemi et al. (2011), Dewan et al. (2012), Akingbogun et al. (2012), Aliyu et al. (2012), Yohanna et al. (2012), Njungbwen et al. (2013), Okeke (2013), Reddy et al. (2013), Krishna et al. (2014), Nmom et al. (2014), Adedeji et al. (2015) utilised geospatial techniques and their results indicated decrease in forest resources due to anthropogenic activities but one of the studies involved human dimension in the method of assessment of the state of the forest. Since man was responsible for deforestation and also at the receiving end, this study combines both Remote Sensing technique and questionnaire survey method in the research design. Multi-temporal Landsat images of 1987, 2002 and 2018 of the study areas, with a resolution of 30 and 28.5 metres were used. Repeated visits to the study area was carried so as to have adequate knowledge of the prevalent and dominant land cover and land use types.

This enabled accurate land use and land cover classification. Snowball sampling technique was employed in the administration of questionnaire to the loggers and farmers in the communities in and around the reserves. This method involved asking an initial contact within a population to identify other potential participants until the required number of sample size is reached. Basically, the population for this study consisted of farmers, timber contractors and forest guards. Six communities were selected from each reserve. The communities chosen are Iguemokhua, Oben, Ugo, Iguere, and Evuarhue and Sakponba for Sokponba forest reserve and for Ehor BC 16/1 forest reserve, Ugiehudu, Eguaholor, Ohe, Uhi, Egbisi and Uhie. These communities were selected because of their proximity to the forest reserves. A total of 100 copies of questionnaire were administered for this purpose across the selected communities.

The study employed the use of Landsat 4, 1987 TM; Landsat 7, 2002 ETM+ and Landsat 8, 2018 OLI/ TIRS images. The three images corresponded with path 189, row 055 and 056 of the WRS-2. The images were cloud-free and had good radiometric quality as reported by the data provider. The entire images are already georeferenced and with a projected coordinates system of WGS 84 UTM Zone 32N.

The clipping of the boundaries of the forest reserves areas, was carried out using ArcGIS 10.1 and a colour composite of band 4, 3 and 2 was created because of its usefulness in vegetation analysis and forest monitoring. These composites were imputed into Environment for Visualising Images (ENVI) software via the external Landsat file format, Geostationary Earth Orbit Tagged Image File Format (GEOTIFF). Supervised classification method was employed by assigning pixel to classes. The knowledge obtained during reconnaissance visits to the study areas was used in the creation of Training Sites. Maximum likelihood classifier algorithm was used in transforming the spectral signature of the training sites into various land use and land cover types present in the study area (Table 1). Several other post classification algorithms such as majority analysis, clump and sieve classes were used to refine the classification.

Change detection statistic was used to compile a detailed tabulation of changes between two classification periods; 1987-2002, 2002-2018 and 1987-2018. While the statistics report included a class for class image difference, the analysis focused primarily on the changes which have occurred in the 
initial state classification. The analysis identified the classes into which pixels changed in the final state. Several methods were adopted to identify, describe and quantify differences between images of the same scene at different times. This was useful in identifying the various classes which change from one class to another. The change statistic report table was divided into two, the initial state classes in the column and the final state classes in the row (Figure 2-13).

Table 1: Description of major land use land cover classification scheme.

\begin{tabular}{ll}
\hline Class & Description \\
\hline Matured forest & Forest with merchantable trees. \\
Light forest & Secondary forest, shrubs and or herbaceous vegetation association \\
Agricultural land & Arable land, permanent crops, pastures and heterogeneous agricultural areas \\
Water & Rivers and streams \\
Settlements & These are villages within or around the reserves \\
\hline
\end{tabular}

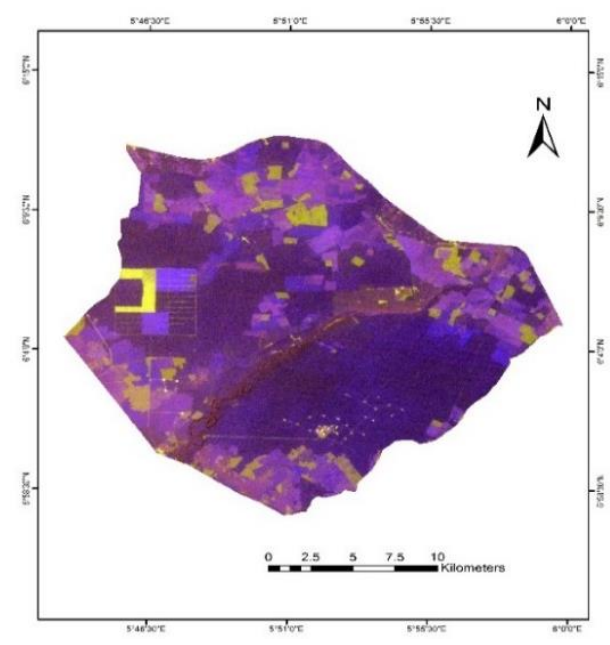

Figure 2. False colour composite of sateliteimagery of sokponba forest reserve for 1987.

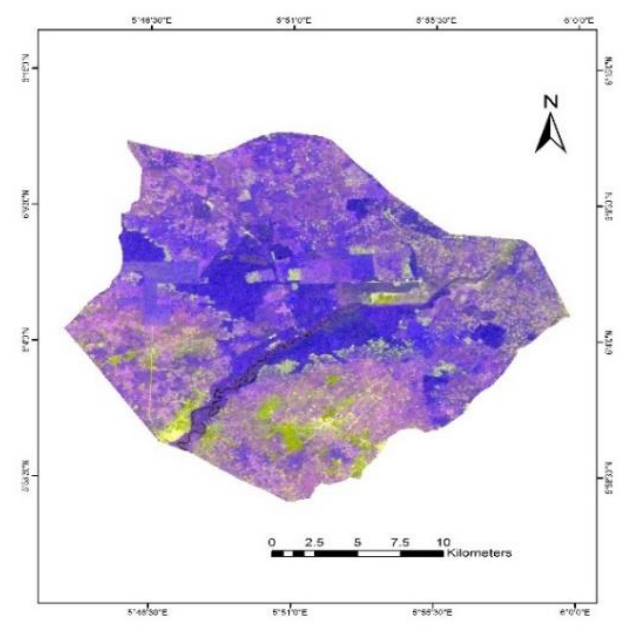

Figure 4. False colour composite of satelite 78 imagery of Sokponba forest reserve for 2002.

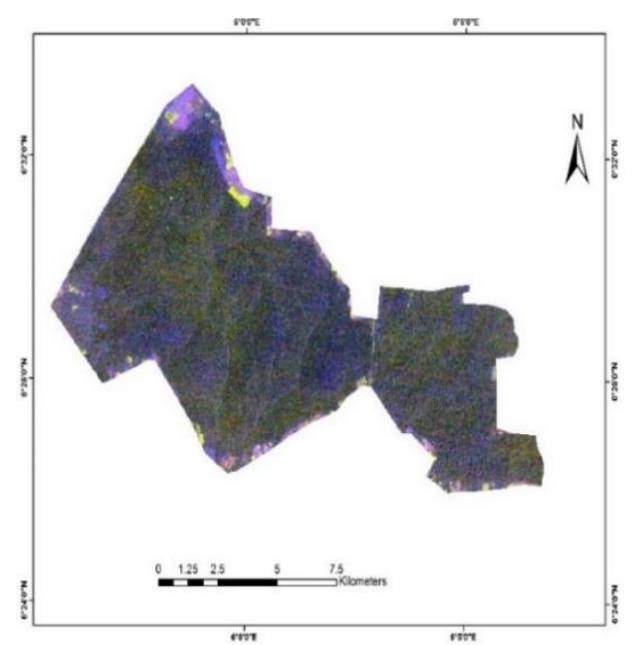

Figure 3. False colour composite satellite imagery of Ehor forest reserve for 1987.

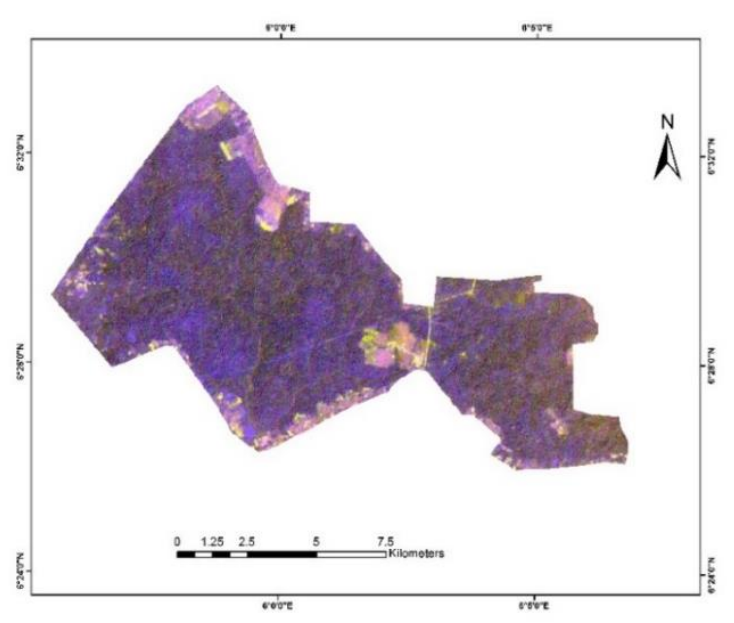

Figure 5. False colour composite satellite imagery of Ehor forest reserve for 2002. 


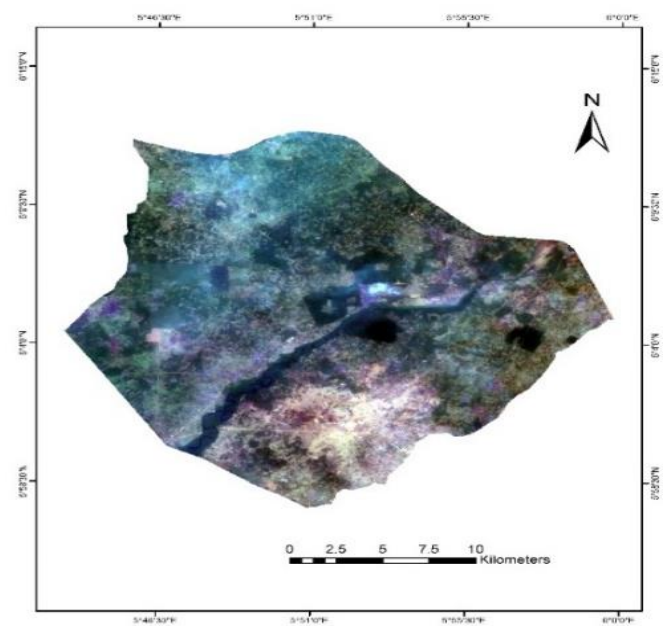

Figure 6. False colour composite of satelite imagery of Sokponba forest reserve for 2018.

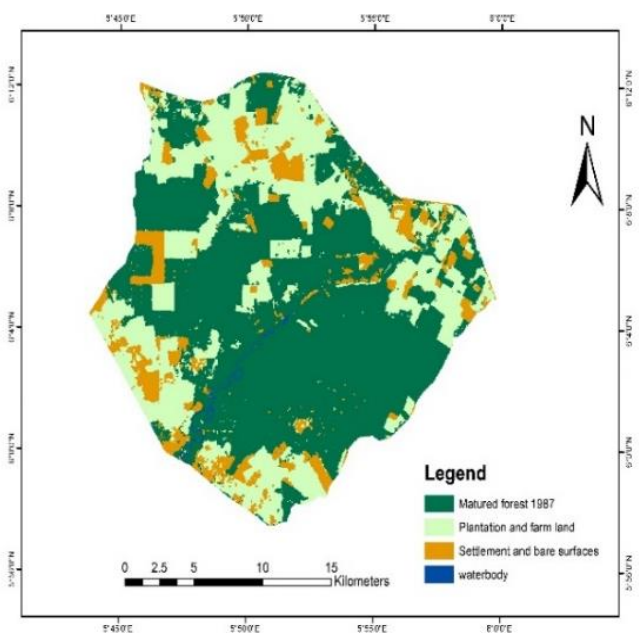

Figure 8. Classified satellite imagery of Sokponba forest reserve for 1987.

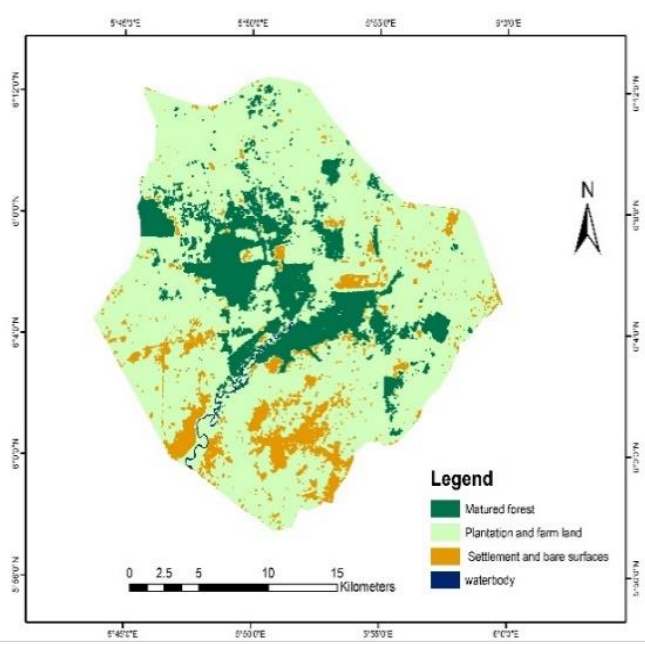

Figure 10. Classified satellite imagery of Sokponba forest reserve for 2002.

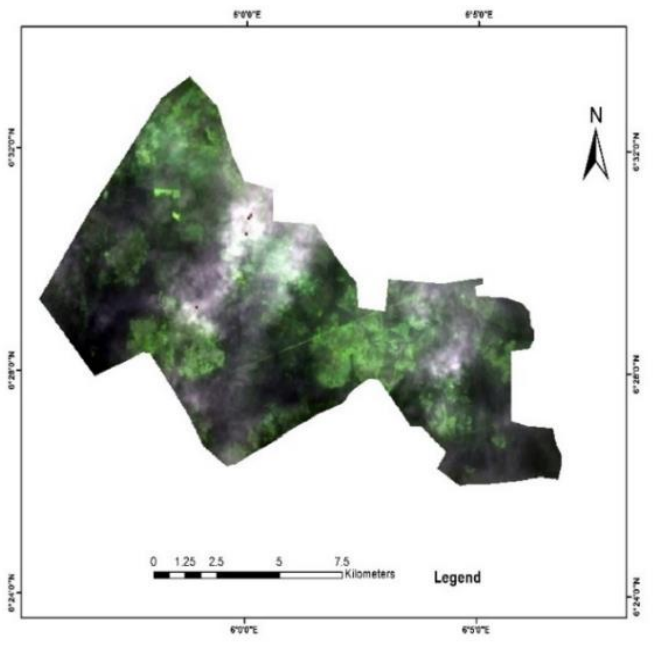

Figure 7. False colour composite satellite imagery of Ehor forest reserve for 2018.

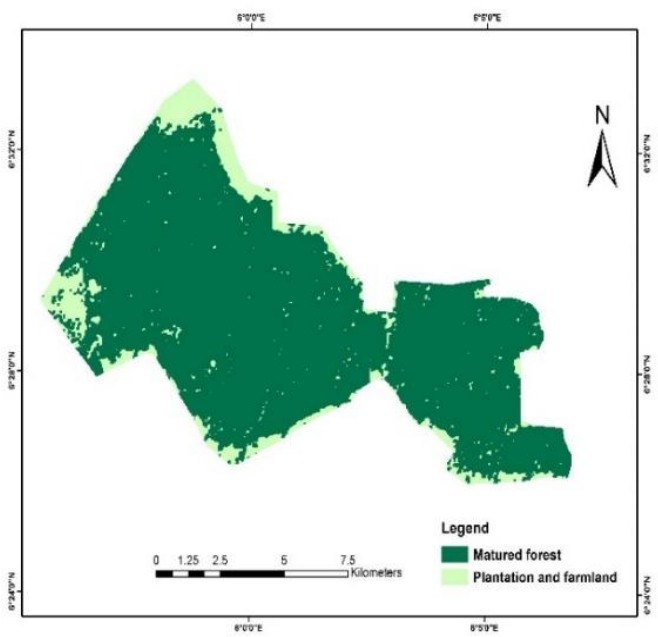

Figure 9. Classified satellite imagery of Ehor forest reserve for 1978.

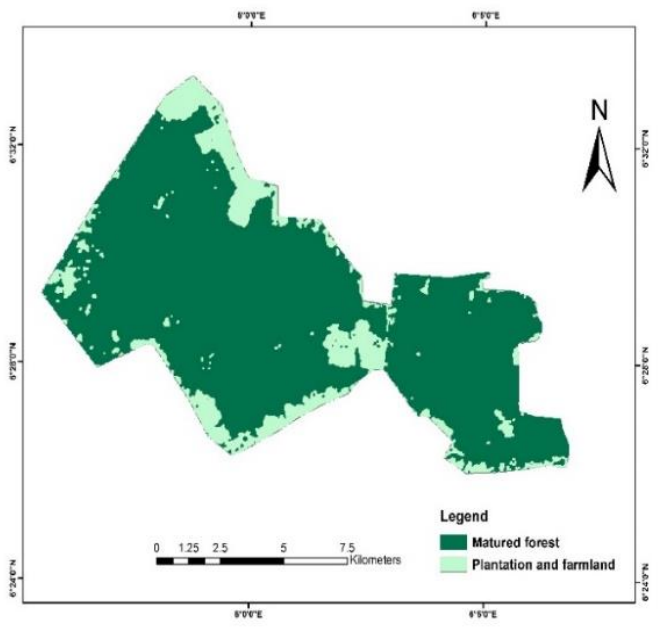

Figure 11. Classified satellite imagery of Ehor forest reserve for 2002. 


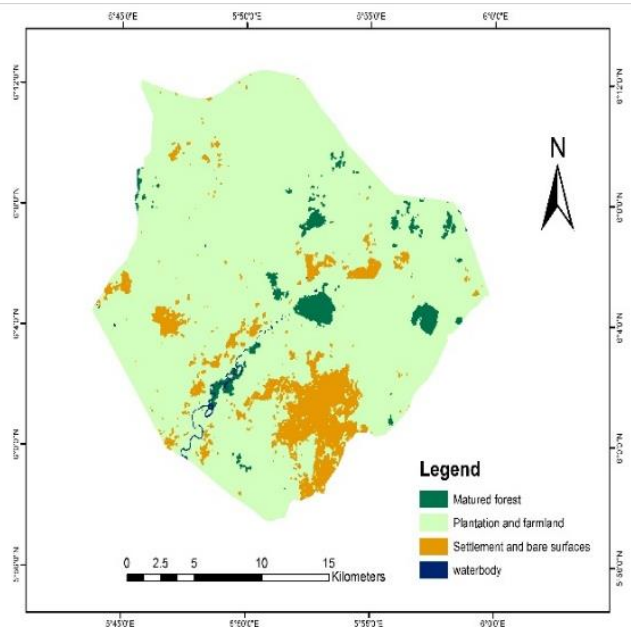

Figure 12. Classified satellite imagery of Sokponba forest reserve for 2018.

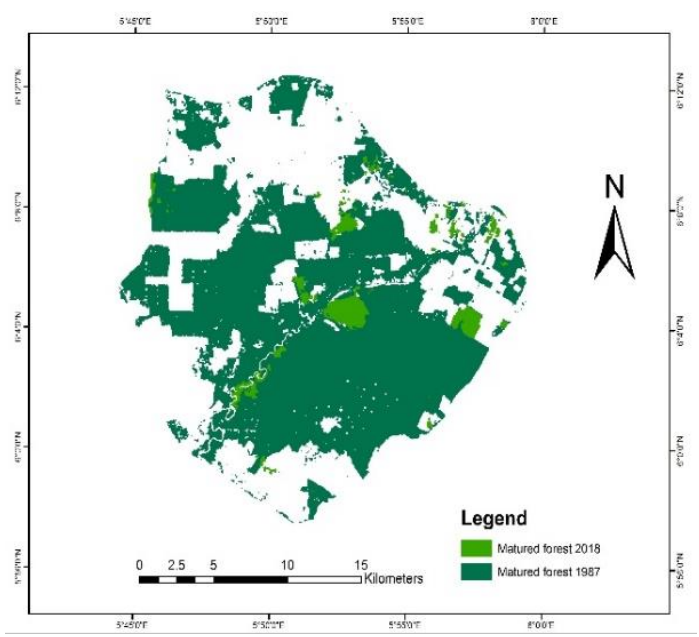

Figure 14. Overlay of classified imagery of Sokponba forest reserve for 1987 and 2018.

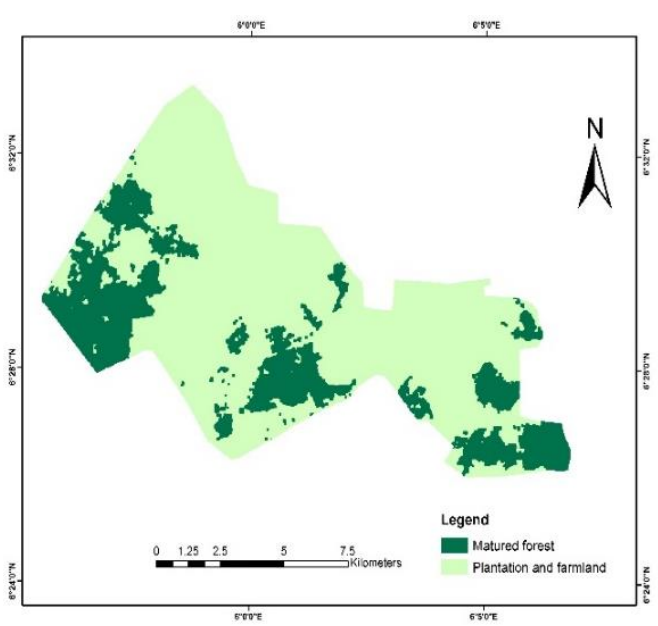

Figure 13. Classified satellite imagery of Ehor forest reserve for 2018.

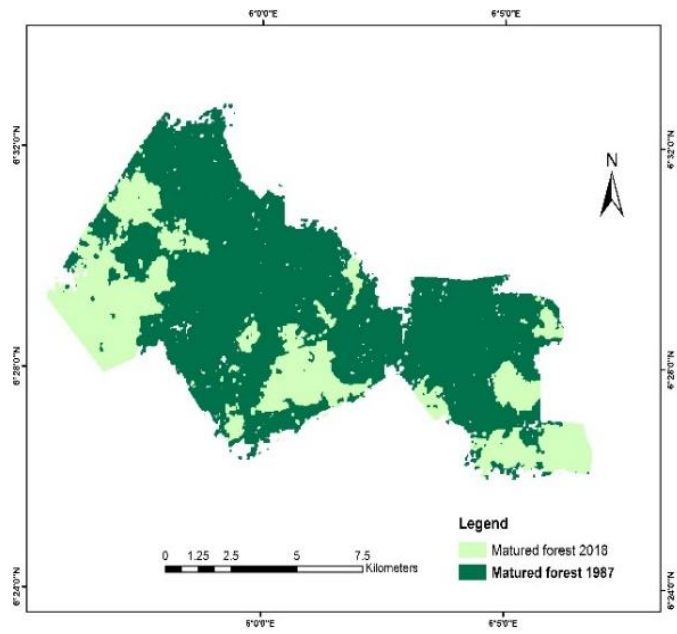

Figure 15. Overlay of classified imagery of Ehor forest reserve for 1987 and 2018.

\section{Results and Discussion}

Accuracy assessments of the classified images were carried out and results (Table 2) showed high level of accuracy (above 84\%). Overlay operation was carried out by superimposing the shapefile of the various classes of land use/ Land cover of 1987, 2002 and 2018 of a particular reserve on each other. The essence of this is to enhance effective visualisation and to determine the extent to which the forest reserves have changed within the period under review. From the result obtained, it is obvious that the forest reserves were severely depleted of its resources, as shown in Figures 8 to 13.

Table 2: Confusion matrix and Kappa coefficient table.

\begin{tabular}{lcc}
\hline Type & Overall accuracy (\%) & Kappa coefficient \\
\hline Sokponba 1987 & $(762 / 839) 90.82$ & 0.8720 \\
Sokponba 2002 & $(683 / 753) 90.70$ & 0.8705 \\
Sokponba 2018 & $(178 / 211) 84.36$ & 0.7642 \\
Ehor BC16/1, 1987 & $(395 / 423) 93.38$ & 0.9003 \\
Ehor BC16/1, 2002 & $(477 / 530) 90.00$ & 0.8499 \\
Ehor BC16/1, 2018 & $(459 / 510) 90.00$ & 0.8503 \\
\hline
\end{tabular}

(Source: Field work, 2019) 


\subsection{Sokponba forest reserve 1987-2018}

The forest reserve within the 31 years period, witnessed a drastic decreased and reduction of the forest resources as only a tiny portion $4.3 \%$ of the entire forest was left (Figure 14). Table 3 reveals that during this period, about $95.714 \%$ of the forest areas were converted mainly to plantation (3.8\%). Also, within this period, there was $12.633 \%$ expansion of settlement and bare surfaces in the areas which were hitherto forest.

The forest reserve was divided into 175 compartments made up of different merchantable species of trees. These compartments were allocated to timber contractors for exploitation by the state government for a fee, which is the major reasons for the forest depletion. Also, illegal lumbering, contributed to deforestation of the forest reserve, likewise farming activities carried out by the people within and outside the forest reserve area.

Table 3: Change in Sokponba forest reserve between 1987 and 2018 at final state.

\begin{tabular}{lrrrrrr}
\hline & \multicolumn{5}{c}{ Initial state } \\
\cline { 2 - 7 } Class & Vegetation & $\begin{array}{c}\text { Settlement } \\
\text { and bare } \\
\text { surfaces }\end{array}$ & $\begin{array}{c}\text { Plantation } \\
\text { and } \\
\text { farmland }\end{array}$ & Water & Row total & Total \\
\hline Unclassified & 0.004 & 0.010 & 0.001 & 0.092 & 0.548 & 100.000 \\
Matured forest & 4.286 & 1.613 & 1.541 & 7.077 & 99.977 & 100.000 \\
Settlement and bare & 12.633 & 9.210 & 3.752 & 0.000 & 99.933 & 100.000 \\
surfaces & 82.973 & 89.072 & 94.683 & 27.757 & 99.917 & 100.000 \\
Plantation and farmland & 0.101 & 0.054 & 0.018 & 65.028 & 99.945 & 100.000 \\
Water & 0.004 & 0.041 & 0.005 & 0.046 & 0.013 & 100.000 \\
Unclass & 100.000 & 100.000 & 100.000 & 100.000 & & \\
Class total & 95.714 & 90.790 & 5.317 & 34.972 & & \\
Class change & -94.542 & -13.416 & 183.203 & -17.004 & & \\
Image difference & & & & &
\end{tabular}

(Source: Field work, 2019)

\subsection{Land change process in Sokponba forest reserve}

Data from Table 4 indicate that within thirty-one years, Sokponba forest reserve, which was $28,913.63$ ha $(57.9 \%)$ in 1987 , decreased to $8,641.33$ ha $(17.3 \%)$ in 2002 . It further decreased drastically to $1,578.15$ ha $(3.2 \%)$ in 2018 . This is alarming. While buildings and bare surface and waterbody decreased, planation and farmland continued to witness tremendous expansion, from 15,357.96 ha $(30.8 \%)$ in 1987 to $36,402.66$ ha $(72.9 \%)$ in 2002 and further increased in size to $43,494.21$ ha $(87.0 \%)$ in 2018.

Table 4: Sokponba 1987-2018, land change process.

\begin{tabular}{lrrrrrr}
\hline Class & $1987(\mathrm{ha})$ & \multicolumn{1}{c}{$\%$} & \multicolumn{1}{c}{$2002(\mathrm{ha})$} & \multicolumn{1}{c}{$\%$} & $2018(\mathrm{ha})$ & \multicolumn{1}{c}{$\%$} \\
\hline Matured forest & $28,913.63$ & 57.90 & $8,641.33$ & 17.30 & $1,578.15$ & 3.20 \\
$\begin{array}{l}\text { Plantation and } \\
\text { farmland }\end{array}$ & $15,357.96$ & 0.80 & $36,402.66$ & 72.90 & $43,494.21$ & 87.00 \\
$\begin{array}{l}\text { Buildings and bare } \\
\text { surface }\end{array}$ & $5,469.48$ & 11.00 & $4,747.50$ & 9.50 & $4,735.71$ & 9.50 \\
$\begin{array}{l}\text { Waterbody } \\
\text { Total }\end{array}$ & 195.84 & 0.39 & 168.66 & 0.34 & 162.54 & 0.33 \\
\hline
\end{tabular}

(Source: Field work, 2019) 


\subsection{Ehor forest reserve (Area BC 16/1) 1987-2018}

Table 5 indicates that Ehor BC 16 forest reserve between 1987 and 2018, a period of 31 years, witnessed a lot of changes in the composition, content and structure of the forest (Figure 15), as only $22.219 \%$ of the total forest reserve area was left. During this period, the forest reserve experienced an alarming rapid deforestation of the forest resources and conversion, with about $73.8 \%$ of the land area converted to plantation and farmland. The loss of the forest can be attributed to the presence of merchantable economic trees in commercial quantities, the allotment of compartments to timber contractors for exploitation by the State government for a fee, illegal lumbering by individuals.

Table 5: Change in Ehor forest reserve between 1987 and 2018 at final state.

\begin{tabular}{lcccc}
\hline \multirow{2}{*}{ Class } & \multicolumn{4}{c}{ Initial state } \\
\cline { 2 - 5 } & Matured forest & $\begin{array}{c}\text { Plantation and } \\
\text { farmland }\end{array}$ & Row total & Class total \\
\hline Unclassified & 0.002 & 0.038 & 0.348 & 100.000 \\
Matured forest & 22.219 & 22.516 & 99.887 & 100.000 \\
Plantation and & 73.773 & 77.326 & 99.878 & 100.000 \\
farm land & - & 0.120 & 0.016 & 100.000 \\
Unclass & 100.000 & 100.000 & - & - \\
Class total & 73.781 & 22.674 & - & - \\
Class change & -70.863 & 554.279 & - & - \\
Image difference & & & &
\end{tabular}

(Source: Field work, 2019)

\subsection{Land change process in Ehor forest reserve}

Table 6 illustrates the land change process which occurred in Ehor forest reserve area. The matured forest as at 1987 was 11,128.86 ha, it reduced in size in 2002 to 10,590.39 ha, though it may be considered very minimal. The forest reserve between 2002 and 2018, witnessed a shocking and alarming depletion of its resource, as a total of 7,348.11 ha of forest land was converted. The reserve reduced to $3,242.28$ ha in 2018.

While the forest kept decreasing in size and resource, plantation and farm land witness increased expansion from $1,424.97$ ha $(11.4 \%)$ in 1987 to $1,970.64$ ha $(15.7 \%)$ in 2002 and to 9,323.28 ha (74.2\%) in 2018. Figure 16 graphically shows the changes in the two forest reserves from 1987 to 2018 in a combine graph.

\begin{tabular}{lrrrrrr}
\hline Class & $1987(\mathrm{ha})$ & \multicolumn{1}{c}{$\%$} & $2002(\mathrm{ha})$ & \multicolumn{1}{c}{$\%$} & $2018(\mathrm{ha})$ & \multicolumn{1}{c}{$\%$} \\
\hline Matured forest & $11,128.86$ & 88.6 & $10,590.39$ & 84.3 & $3,242.28$ & 25.8 \\
$\begin{array}{l}\text { Plantation and } \\
\text { farmland }\end{array}$ & $1,424.97$ & 11.4 & $1,970.64$ & 15.7 & $9,323.28$ & 74.2 \\
Total & $12,553.83$ & 100.0 & $12,561.03$ & 100.0 & $12,565.56$ & 100.0 \\
\hline
\end{tabular}

Table 6: Ehor, 1987-2018, land change process.

Total

(Source: Field work, 2019)

The genders composition of the respondents to the questionnaire administered to the residents of communities in and around Ehor and Sakponba forest reserves shows that $57.0 \%$ were males, while females were 43.0\%. Among the respondents, $24.0 \%$ do not have formal education, $39.0 \%$ had education up to the primary school level while $21.0 \%$ of them attended secondary school, $16.0 \%$ of the 
respondents have tertiary education. It could be said that majority of the population is literate and could understand the questions administered to them. Majority $(87.0 \%)$ of the respondents are farmers while timber contractor accounts for $13.0 \%$. This shows that farming and logging are the major activities going on in the various forest reserves.

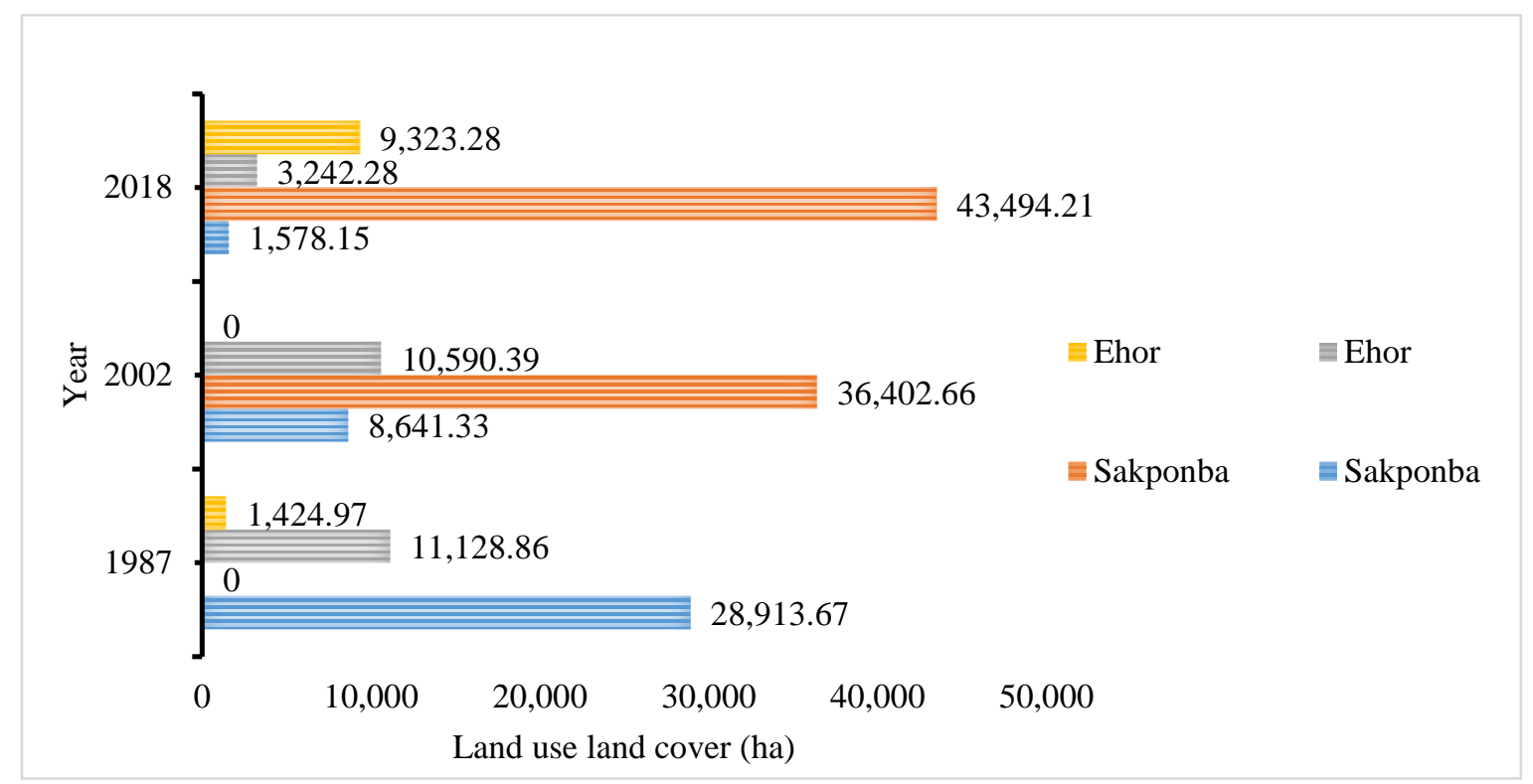

Figure 16. Land use land cover statistics of the reserves 1987-2018.

About $28.0 \%$ of the respondents have stayed for 1-5 years, those who have stayed for 6-10 years were $12.0 \%$, also $5.0 \%$ of them have stayed for $11-20$ years and $51.0 \%$, have stayed for 20 years and above. More than half of the respondents have stayed long enough to give informed response to the questionnaire. About $75.0 \%$ of the farmers carry out their farming operations in the reserve, $12.0 \%$ farm in free areas while $13.0 \%$ of the respondent did not indicate the location of their farm lands. Among the farmers, $41.0 \%$ indicated that they got their farm land from the government, $28.0 \%$ from the communities, while $9.0 \%$ of the respondents got theirs from individuals and $2.0 \%$ of the people decided to farm in the reserves without permission from anybody. About $20.0 \%$ of the farmers did not return answer to the question on source of their farmland.

Farmers who make use of the reserve pay certain amount of money for the use of the land annually. About $69.0 \%$ of the respondents affirm that they pay below $\mathrm{N} \mathrm{100,000} \mathrm{per} \mathrm{hectare} \mathrm{of} \mathrm{land}$ while $1.0 \%$ says that they pay above N 100,000 per hectare of land. About $30.0 \%$ of the respondent decline answers to this question. Findings further reveals that about $31.0 \%$ of the respondents have been farming there for about 1-5 years, 33.0\% for about 6-10 years while 4.0\% and 6.0\%, have spent 11-20 years and above 20 years respectively. This long numbers of years that farming has been taken place in the reserves account partly for the current state of the reserves.

Analysis shows that $3.0 \%$ of the timber contractors have been operating in the reserves for about 1-5 years, while $6.0 \%$ have worked there for 6-10 years. Information from timber contractors shows that $6.0 \%$ of loggers carry out their logging activities in the state government allotted compartment while about $3.0 \%$ illegally exploit the forest resources, $2.0 \%$ of the contractor operates in free areas and $2.0 \%$ operates both in the reserves as well as free areas. Majority (87\%) of loggers decline response to the question. Information shows that timber contractors who are allotted compartments in the reserves pay various amount of money to the government. About $1.0 \%$ of the contractor agreed that they pay between 
$\mathrm{N}$ 200,000-400,000 per compartment, 5.0\% pay between $\mathrm{N} 400,001-600,000$ and 3.0\%, pay above $\mathrm{N}$ 600,000 . Though $91 \%$ of loggers did not return answer to this question their response may not be too far from others.

This study assessed Sokponba and Ehor forest reserves using geospatial tools and questionnaire survey to identify the extent of deforestation and the factors responsible for the deforestation. The study reveals that there has been an alarming reduction in the size, content and structure of the forest reserves areas. The Sokponba forest reserve which had a total of 28,913.67 ha of forest land in 1987, had only about 1,578.15 ha left in 2018. Within the 31 years period, the forest reserve loss about 27,335.52 ha to other land use types. On the other hand, plantation and farmland increased from 15,357.96 ha in 1987, to 36,402.66 ha, in 2002 and to 43,494.21 by 2018. Likewise, Ehor BC16/1, recorded reduction in the forest land area from 11,128.86 ha in 1987, to 3,242 ha in 2018. About 7,886.58 ha of the forest area was deforested. In the same vein, plantation and farmland increased from 1,424.97 ha, 1,970.64 ha and 9,323.28 ha, in 1987, 2002 and 2018 respectively.

According to Eseigbe and Oni (2018), lack of comprehensive policies on environmental laws and issues, inadequate legal framework and lack of implementation of the forest Act of 1999 are some of the major reasons why people still encroach forest reserves. The forest reserves which were once dense with vegetation, has been depleted of its forest resources, thereby leaving the reserve almost devoid of economic trees. The current state of the reserves with little or no forest remaining, negated the essence of its delineation as forest reserves areas. The deliberate government policies of allocating compartment to timber contractors for logging, as well as land concession to multinational firms and private individuals for oil palm plantation are the factors that were responsible for the depletion of the forest reserves. There is no deliberate attempt by the State government to plant trees in the deforested areas, instead most part of the reserves have been de-reserved to make room for farmers who pay per hectare for oil palm, rubber, cocoa, plantain and pineapple plantations.

\section{Conclusion}

As deforestation is taking place in these two reserves under study the same thing is happening in other reserves in the state. It has been observed that at the inception, forest reservation was $25 \%$ of the total land area of the state but currently it is less than 5\% (Kalum et al., 2010). It could be rightly said that urgent need for fund by the state government overrides the initial purpose of creating the reserve. It also indicates that the need of the presence is not taking into consideration the need of the future generation which negate the concept of sustainability. The environmental consequences of this deforestation is already manifesting in the number of gully erosion sites in the state. Besides, the implications of deforestation on global warming demands that a lot of efforts and strategies has to be adopted in other to address the current trend. It is recommended that the government should stop allocating these compartments, in other to preserve the remaining patches of forest. The government should adopt taungya farming system, by planting of exotic trees in places which have been converted to farm lands and put in measures to check that these afforested areas are not deforested again.

\section{References}

Adedeji, O.H., Tope-Ajayi, O.O. and Abegunde, O.L., 2015. Assessing and predicting changes in the status of Gambari forest reserve, Nigeria using remote sensing and GIS techniques. Journal of Geographic Information System, 7:301-318.

Aliyu, M.G., and Abdullahi, L.T., 2014. Assessment of environmental changes in the Fufore area of Adamawa state, Nigeria. IOSR Journal of Environmental Science, Toxicology and Food Technology (IOSR-JESTFT). 
Ati, O.F., Sheyin, T., Abbas, I. and Muhammad, S., 2010. Assessing changes in Kagoro forest, Kaduna state Nigeria using remote sensing and GIS. Research Journal of Applied Sciences, Engineering and Technology, 2:121-132.

Akingbogun, A.A., Kosoko, O.S.O.A. and Aborisade, D.K., 2012. Remote sensing and GIS application for forest reserve degradation prediction and monitoring. In: First FIG Young Surveyors Conference Knowing to Create the Future, Rome, 4-5 May 2012, pp. 1-27.

Aweto, A.O., 1990. Plantation forestry and forest conservation in Nigeria. The Environmentalist, 10:2734.

Batta, H., Ashong, C.A. and Bashir, A.S., 2013. Press coverage of climate change issues in Nigeria and implications for public participation opportunities. Journal of Sustainable Development, 6.

Dewan, A.M., Yamaguchi, Y. and Rahman, M.Z., 2012. Dynamics of land use/cover changes and the analysis of landscape fragmentation in Dhaka metropolitan, Bangladesh. GeoJournal, 77:315330.

Eseigbe, J.O. and Oni, M.I., 2018. Legal and regulatory reforms of forest resources conservation in Edo south, Edo state, Nigeria. Journal of Law, Policy and Globalization, 72:38.

Farlex, A., 2014. Forest reserve-Definition of forest reserve. www.thefreedictionary.com/forest+reserve. Accessed 10 June 2014.

Food and Agriculture Organization (FAO), 2010. Global forest resources assessment 2010: Main report, FAO Forestry paper, 163.

Fearnside, P.M. and Barbosa, R.I., 2004. Accelerating deforestation in Brazilian Amazonia: Towards answering open questions. Environment Conservation, 31:7-10.

Foody, G.M., 2003. Remote sensing of tropical forest environments: Towards the monitoring of environmental resources for sustainable development. International Journal of Remote Sensing, 4035-4046.

Kalu, C. and Ilavbarhe, K.O., 2010. Competitive land rents: The bane of forest conservation in Edo state, Nigeria. Research Journal of Forestry, 4:179-184.

Kumar, D., Borah, S. and Shankar, U., 2010. Temporal forest cover change monitoring in chakrashila wildlife sanctuary, Assam, India using Remote Sensing and GIS. Communicated data.

Mmom, P.C. and Mbee, M.D., 2014. Population pressure and forest resource depletion in Gele Gele forest reserve of Edo state. Nigeria International Journal of Physical and Human Geography, 2:10-21.

Gunlycke, N. and Tuomaala, A., 2011. Detecting forest degradation in Marakwet district, Kenya, using remote sensing and GIS. In: cooperation with SCC-Vi Agroforestry: a minor field study. Lunds universitets Naturgeografiska institution-Seminarieuppsatser.

Njungbwen, E. and Mbakwe, R.., 2013. A GIS and remote sensing approach to assessment of deforestation in Uyo, Akwa Ibom state Nigeria. Ethiopian Journal of Environmental Studies and Management, 6.

Oduntan, O.O., Soaga, J.A.O., Akinyemi, A.F. and Ojo, S.O., 2013. Human activities, pressure and its threats on forest reserves in Yewa division of Ogun state, Nigeria. E3 Journal of Environmental Research and Management, 4:260-267.

Ojonigu, F.A., Sheyin, T., Abbas, I. and Mohammed, S.O., 2009. Assessing changes in Kagoro forest, Kaduna state Nigeria using remote sensing and GIS. Research Journal of Applied Sciences, Engineering and Technology, 2:121-132.

Okeke, O.F., 2013. Land cover change analysis in the Afi-Mbe-Okwangwo landscape, Cross River state, Nigeria. www.wcsnigeria.org. Accessed 20 June 2015.

Olakunle, O.F., Omotayo, A. and Odewumi, S.G., 2011. Pattern and problems of deforestation in Southwestern Nigeria. International Journal of Academic Research, 3. 
Oyebo, M.A., 2006. History of forest management in Nigeria from 19th century to date. In: Salami, A.T. (Ed.). In: Imperatives of Space Technology for Sustainable Forest Management in Nigeria. Proceedings of an International Stakeholders Workshop Sponsored by National Space Research and Development Agency, Abuja, pp. 1-14.

Reddy, C.S., Sreelekshmi, S., Jha, C.S. and Dadhwal, V.K., 2013. National assessment of forest fragmentation in India: landscape indices as measures of the effects of fragmentation and forest cover change. Ecological. Engineering Journal, 60:453-464.

Krishna, P.H., Saranya, K.R.L., Reddy, C.S., Jha, C.S. and Dadhwal, V.K., 2014. Assessment and monitoring of deforestation from 1930 to 2011 in Andhra Pradesh, India using remote sensing and collateral data. Current Science, 867-875.

Usman, B.A., and Adefolalu, L.L., 2010. An appraisal of Nigerian national policy on forestry, wildlife and protected Areas. Environmental Issues, 3:50.

Yohanna, P., Innocent, R. and Emmanuel, B., 2012. The application of remote sensing and geographic information system (GIS) for monitoring deforestation in south-west Nigeria. Journal of Environmental Issues and Agriculture in Developing Countries, 4:6-11. 